\title{
Knowledge Level of Tribal Farmers Regarding Parthenium (Parthenium hysterophorus L.) Weed and their Control Actions
}

\author{
D.V. Singh ${ }^{1^{*}}$, Anupam Mishra ${ }^{2}$, S.R.K. Singh ${ }^{3}$ and Tushar Athare ${ }^{3}$ \\ ${ }^{1}$ Krishi Vigyan Kendra, Kandhamal, OUAT, Bhubaneswar, India \\ ${ }^{2}$ ICAR- ATARI, Zone-IX, Jabalpur, India \\ ${ }^{3}$ Agricultural Extension, ICAR- ATARI, Zone-IX, Jabalpur, India \\ *Corresponding author
}

\begin{tabular}{|c|}
\hline Keywords \\
\hline $\begin{array}{l}\text { Allelopathic } \\
\text { substance, Control } \\
\text { measures, } \\
\text { Knowledge level, } \\
\text { Parthenium weed. }\end{array}$ \\
\hline Article Info \\
\hline $\begin{array}{l}\text { Accepted: } \\
28 \text { October } 2017 \\
\text { Available Online: } \\
10 \text { December } 2017\end{array}$ \\
\hline
\end{tabular}

\section{Introduction}

Parthenium hysterophorus L. commonly called as carrot weed, white top or congress grass in India is a herbacious erect and annual plant belongs to family Asteracae (Compositae). The origin of Parthenium is considered to be Mexico, America, Trinidad and Argentina. Within last 100 years, it has found its way to Africa, Australia and Asia. In Australia and India, Parthenium has achieved the status of "worst weed". It's surmised that Parthenium possibly got entry from USA through the imported food grains (Vertak, 1968) or through the cereals got for experimental purpose (Lonkar et al., 1974). In 
most of the publications, first occurrence of Parthenium in India has believed to be in 1956 when it was first noticed by a retired horticulturist Prof. Paranjape and described by Rao (1956).

According to Mahadevappa (1996), Parthenium status, in terms of its seriousness in different states of India is Uttar Pradesh, Karnataka, Maharashtra, Tamil Nadu, Andhra Pradesh, West Bengal, Madhya Pradesh, Gujarat, Orissa and Bihar, in that order of magnitude, contrary to earlier observations when it was categorized as serious weed of Maharashtra, Karnataka, Andhra Pradesh and Delhi (Krishnamurthy et al., 1976). The Parthenium intensity has been estimated less in high elevation. It is estimated that about 5 million ha area has been invaded by Parthenium in India.

\section{Environmental and other impacts}

Parthenium hysterophorus has been reported to cause skin rashes (dermatitis), on those parts of the body that come in contact with the weed on a regular basis, watery eyes, swelling and itching of the membranes of the mouth and nose, constant coughing especially at night, continually running nose and sneezing, itching of the roof of the mouth and fatigue.

Allergy-prone people are particularly susceptible to both the dermatitis and respiratory problems. The weed is unpalatable to livestock so its invasion results in grazing shortages. If it is mixed with fodder, it taints meat and milk. In Southern Africa, this weed is particularly problematic in sugarcane and banana plantations.

It produces allelopathic substances that deter other plants from germinating and growing near it and hence can "take over" native grassland and improved livestock pastures as well as the understory in woodlands.

\section{Materials and Methods}

The study was conducted in Kandhamal district of Odisha State during the year 20152016. Out of total twelve blocks in Kandhamal district only two blocks namely G. Udayagir and Rakia were selected purposively for this study. Eight villages from each block were selected randomly and 8 farmers from each village were selected randomly, the total 64 farmers from each block were selected. Thus, the total 128 farmers from two blocks were selected randomly for the study. Data was collected through appropriate pre-tested interview schedule. Collected data was analyzed through appropriate statistical tools.

\section{Results and Discussion}

The data presented in table 1 indicate that out of total respondents majority $(56.25 \%)$ of them had medium level of knowledge regarding control measure practices of Parthenium weed, whereas, 35.93 and 7.82 per cent of the respondents were having high and low level of knowledge, respectively. It can be concluded that majority of the respondents had medium level of knowledge regarding control measure practices of Parthenium weed.

The data represented in table 2 indicated that majority of the respondents $(60.95 \%)$ had medium level of knowledge about Parthenium weed; followed by 21.87 per cent respondents were having high level of knowledge about Parthenium weed, whereas 17.18 per cent respondents had low knowledge about Parthenium weed. It was found that majority of the respondents $(58.59 \%)$ had low level of knowledge about distribution on field, whereas, 26.56 and 14.85 per cent of the respondents were having medium and high level of knowledge, respectively knowledge about distribution on field. 
It was observed that majority of the respondents $(50.78 \%)$ had medium level of knowledge about total spread area 33.59 and 15.63 per cent of the respondents were having low and high level of knowledge, respectively knowledge about total spread area.

It was found that majority of the respondents (75.00\%) had low level of knowledge about other name, whereas, 14.06 and 10.94 per cent of the respondents were having high and medium level of knowledge, respectively regarding knowledge about other name. It was observed that majority of the respondents $(50.00 \%)$ had medium level of knowledge about propagation, whereas, 40.63 and 9.37 per cent of the respondents were having low and high level of knowledge, respectively regarding knowledge about propagation.

It was observed that majority of the respondents $(47.65 \%)$ had low level of knowledge about life cycle, 32.81and 19.54 per cent of the respondents were having medium and high level of knowledge, respectively regarding knowledge about life cycle. It was found that maximum number of the respondents $(49.22 \%)$ had low level of knowledge about seed production, whereas, 31.25 and 19.53 per cent of the respondents were having medium and high level of knowledge, respectively regarding knowledge about seed production. It was found that majority of the respondents (58.59\%) had low level of knowledge about identification of seed, whereas, 26.56 and 14.85 per cent of the respondents were having medium and high level of knowledge, respectively regarding knowledge about identification of seed.

It was found that majority of the respondents (49.23\%) had low level of knowledge about type and condition of soil for seed germination, whereas, 35.15 and 15.62 per cent of the respondents were having medium and high level of knowledge, respectively regarding knowledge about type and condition of soil for seed germination. It was observed that majority of the respondents (67.96\%) had low level of knowledge about reason of Parthenium weed distribution, 20.33 and 11.71 per cent of the respondents were having medium and high level of knowledge, respectively regarding knowledge about reason of Parthenium weed distribution.

It was found that majority of the respondents (58.59\%) had low level of knowledge regarding knowledge about harmful effect, whereas, 28.90 and 12.51 per cent of the respondents were having medium and high level of knowledge, respectively regarding knowledge about harmful effect. It was observed that majority of the respondents $(85.15 \%)$ had low level of knowledge regarding knowledge about harmful effects on human health, 8.59 and 6.26 per cent of the respondents were having medium and high level of knowledge, respectively regarding knowledge about harmful effects on human health.

It was found that majority of the respondents (94.54\%) had low level of knowledge regarding knowledge about identification of skin allergy through patch test, followed by 5.46 per cent respondents who were having medium knowledge regarding knowledge about identification of skin allergy through patch test, whereas none of the respondents were having high level of knowledge regarding knowledge about identification of skin allergy through patch test.

It was observed that majority of the respondents $(97.66 \%)$ had low level of knowledge regarding knowledge about harmful effect on animals, 1.56 and 0.78 per cent of the respondents were having medium and high level of knowledge, respectively regarding knowledge about harmful effect on animals. 
Majority of the respondents $(100 \%)$ had low level of knowledge regarding knowledge about hair loss of animals due to consumption of Parthenium weed, whereas, none of the respondents were having medium and high level of knowledge, respectively regarding knowledge about hair loss of animals due to consumption of Parthenium weed. It was found that maximum number of the respondents $(95.32 \%)$ had low level of knowledge regarding knowledge about problem of diarrhoea causes by consumption of Parthenium weed in animals, whereas, 2.34 and 1.56 per cent of the respondents were having medium and high level of knowledge, respectively regarding knowledge about diarrhoea causes by consumption of Parthenium weed in animals.

Majority of the respondents $(96.87 \%)$ had low level of knowledge regarding knowledge about skin allergy causes by consumption of Parthenium weed in animals, whereas, 2.35 and 0.78 per cent of the respondents were having medium and high level of knowledge, respectively regarding knowledge about skin allergy causes by consumption of Parthenium weed in animals. It was found that majority of the respondents $(72.65 \%)$ had low level of knowledge regarding knowledge about effects on agriculture, whereas, 19.53 and 7.82 per cent of the respondents were having medium and high level of knowledge, respectively regarding knowledge about effects on agriculture, It was observed that majority of the respondents $(60.93 \%)$ had low level of knowledge regarding knowledge about effects on crop production area and production, 29.68 and 9.38 per cent of the respondents were having medium and high level of knowledge, respectively regarding knowledge about effects on crop production area and production.

Majority of the respondents $(60.95 \%)$ had low level of knowledge regarding knowledge about effects on seed germination and growth of other crops, whereas, 30.46 and 8.59 per cent of the respondents were having medium and high level of knowledge, respectively regarding knowledge about effects on seed germination and growth of other crops.

It was found that majority of the respondents (58.59\%) had low level of knowledge regarding knowledge about more effects on different crops, whereas, 27.35 and14.06 per cent of the respondents were having medium and high level of knowledge, respectively regarding knowledge about more effects on different crops.

It was observed that majority of the respondents $(65.62 \%)$ had low level of knowledge regarding knowledge about effects on soil condition, 24.21 and 10.15 per cent of the respondents were having medium and high level of knowledge, respectively regarding knowledge about effects on soil condition.

Table.1 Distribution of respondents according to their overall level of knowledge regarding control measure practices of Parthenium weed $(\mathrm{N}=128)$

\begin{tabular}{|c|l|c|c|}
\hline S. No. & Overall level of knowledge & Frequency & Percent \\
\hline 1 & Low (below 56 score) & 46 & 35.93 \\
\hline 2 & Medium (56-69 score) & 72 & 56.25 \\
\hline 3 & High (above 69 score) & 10 & 7.82 \\
\hline & Total & $\mathbf{1 2 8}$ & $\mathbf{1 0 0 . 0 0}$ \\
\hline
\end{tabular}

$\bar{X}=62.50 \mathrm{SD}=5.59$ 
Table.2 Distribution of respondents according to their level of knowledge regarding control measures practices Parthenium weed $(\mathrm{N}=128)$

\begin{tabular}{|c|c|c|c|c|}
\hline \multirow[t]{2}{*}{ S. No. } & \multirow[t]{2}{*}{ Practices } & \multicolumn{3}{|c|}{ Level of knowledge } \\
\hline & & $\begin{array}{c}\text { Low } \\
\text { f/percent }\end{array}$ & $\begin{array}{l}\text { Medium } \\
\text { f/percent }\end{array}$ & $\begin{array}{c}\text { High } \\
\text { f/percent }\end{array}$ \\
\hline 1 & Knowledge about Parthenium weed & $22(17.18)$ & $78(60.94)$ & $28(21.87)$ \\
\hline 2 & Distribution on field & $75(58.59)$ & $34(26.56)$ & $19(14.84)$ \\
\hline 3 & Total spread area & $43(33.59)$ & $65(50.78)$ & $20(15.62)$ \\
\hline 4 & Other name & $96(75.00)$ & $14(10.94)$ & $18(14.06)$ \\
\hline 5 & Propagation & $52(40.62)$ & $64(50.00)$ & $12(9.38)$ \\
\hline 6 & Life cycle & $61(47.65)$ & $42(32.81)$ & $25(19.53)$ \\
\hline 7 & Seed production & $63(49.21)$ & $40(31.25)$ & $25(19.53)$ \\
\hline 8 & Identification of seed & $75(58.59)$ & $34(26.56)$ & $19(14.84)$ \\
\hline 9 & $\begin{array}{l}\text { Type and condition of soil for seed } \\
\text { germination }\end{array}$ & $63(49.21)$ & $45(35.16)$ & $20(15.62)$ \\
\hline 10 & Reason of Parthenium weeds distribution. & $87(67.96)$ & $26(20.31)$ & $15(11.72)$ \\
\hline 11 & Harmful effect & $75(58.59)$ & $37(28.91)$ & $16(12.50)$ \\
\hline 12 & Harmful effects on human health & $109(85.15)$ & $11(8.59)$ & $8(6.25)$ \\
\hline 13 & $\begin{array}{l}\text { Identification of skin allergy through patch } \\
\text { test }\end{array}$ & $121(94.53)$ & $7(5.47)$ & $0(0.00)$ \\
\hline 14 & Harmful effects on animals & $125(97.65)$ & $2(1.56)$ & $1(0.87)$ \\
\hline 15 & $\begin{array}{l}\text { Hair loss of animals due to consumption of } \\
\text { Parthenium weed }\end{array}$ & $128(100)$ & $0(0.00)$ & $0(0.00)$ \\
\hline 16 & $\begin{array}{l}\text { Diarrhoea causes by consumption of } \\
\text { Parthenium weed in animals }\end{array}$ & $122(95.31)$ & $4(3.12)$ & $2(1.56)$ \\
\hline 17 & $\begin{array}{l}\text { Skin allergy causes by consumption of } \\
\text { Parthenium weed in animals }\end{array}$ & $124(96.87)$ & $3(2.34)$ & $1(0.78)$ \\
\hline 18 & Effects on agriculture & $93(72.65)$ & $25(19.53)$ & $10(7.81)$ \\
\hline 19 & $\begin{array}{l}\text { Effects on crop production area and } \\
\text { production }\end{array}$ & $78(60.93)$ & $38(29.69)$ & $12(9.38)$ \\
\hline 20 & $\begin{array}{l}\text { Effects on seed germination and growth of } \\
\text { other crops }\end{array}$ & $78(60.93)$ & $39(30.47)$ & $11(8.59)$ \\
\hline 21 & More effects on different crops & $75(58.59)$ & $35(27.34)$ & $18(14.06)$ \\
\hline 22 & Effects on soil condition & $84(65.62)$ & $31(24.22)$ & $13(10.16)$ \\
\hline 23 & Presence of lot of hidden disease & $107(83.59)$ & $11(8.59)$ & $10(7.81)$ \\
\hline 24 & $\begin{array}{l}\text { Scientific methods of Parthenium weed } \\
\text { control }\end{array}$ & $112(87.50)$ & $10(7.81)$ & $6(4.69)$ \\
\hline 25 & Mechanical method & $92(71.87)$ & $25(19.53)$ & $11(8.59)$ \\
\hline 26 & Uprooting method & $78(60.93)$ & $37(28.91)$ & $13(10.16)$ \\
\hline 27 & Precaution during uprooting method & $101(78.90)$ & $19(14.84)$ & $8(6.25)$ \\
\hline 28 & Cultural method & $101(78.90)$ & $23(17.97)$ & $4(3.12)$ \\
\hline 29 & Advantages of cultural method & $111(86.71)$ & $12(9.37)$ & $5(3.91)$ \\
\hline 30 & Legal method & $128(100)$ & $0(0.00)$ & $0(0.00)$ \\
\hline 31 & Utilization method & $128(100)$ & $2(1.56)$ & $0(0.00)$ \\
\hline
\end{tabular}




\begin{tabular}{|c|l|l|c|c|}
\hline 32 & $\begin{array}{l}\text { Use of Parthenium weed as insecticidal and } \\
\text { nematicidal form }\end{array}$ & $127(99.22)$ & $1(0.78)$ & $0(0.00)$ \\
\hline 33 & For making acid and biogas & $127(99.22)$ & $1(0.78)$ & $0(0.00)$ \\
\hline 34 & For making card board & $128(100)$ & $0(0.00)$ & $0(0.00)$ \\
\hline 35 & Use of Parthenium weed on sericulture & $128(100)$ & $0(0.00)$ & $0(0.00)$ \\
\hline 36 & For making compost & $128(100)$ & $0(0.00)$ & $0(0.00)$ \\
\hline 37 & $\begin{array}{l}\text { Use of Parthenium weed which stage on } \\
\text { composting }\end{array}$ & $128(100)$ & $0(0.00)$ & $0(0.00)$ \\
\hline 38 & $\begin{array}{l}\text { Nutrient status of Parthenium weed } \\
\text { compost }\end{array}$ & $128(100)$ & $0(0.00)$ & $0(0.00)$ \\
\hline 39 & Chemical method & $120(93.75)$ & $4(3.12)$ & $4(3.12)$ \\
\hline 40 & Chemical quantity & $126(98.43)$ & $0(0.00)$ & $2(1.56)$ \\
\hline 41 & $\begin{array}{l}\text { When chemical method is applied according to } \\
\text { day and time-interval }\end{array}$ & $123(96.09)$ & $2(1.56)$ & $3(2.34)$ \\
\hline 42 & Precaution during chemical method & $123(96.09)$ & $1(0.78)$ & $4(3.12)$ \\
\hline 43 & Salt solution method & $127(99.22)$ & $0(0.00)$ & $1(0.78)$ \\
\hline 44 & Biological methods & $127(99.22)$ & $0(0.00)$ & $1(0.78)$ \\
\hline 45 & Fungal method & $127(99.22)$ & $0(0.00)$ & $1(0.78)$ \\
\hline 46 & Bacterial method & $128(100)$ & $0(0.00)$ & $0(0.00)$ \\
\hline 47 & Insect method & $127(99.22)$ & $0(0.00)$ & $1(0.78)$ \\
\hline 48 & Cultural method & $127(99.22)$ & $1(0.78)$ & $0(0.00)$ \\
\hline 49 & Flowers method & $128(100)$ & $0(0.00)$ & $0(0.00)$ \\
\hline 50 & Other methods & $128(100)$ & $0(0.00)$ & $0(0.00)$ \\
\hline 51 & $\begin{array}{l}\text { Surrounding area covered under } \\
\text { Parthenium weed }\end{array}$ & $42(32.82)$ & $51(39.84)$ & $35(27.34)$ \\
\hline 52 & $\begin{array}{l}\text { Field area which is effected by Parthenium } \\
\text { weed }\end{array}$ & $71(55.47)$ & $35(27.34)$ & $22(17.18)$ \\
\hline 53 & Yield loss due to Parthenium weed & $88(68.75)$ & $20(15.62)$ & $20(15.62)$ \\
\hline & & & \\
\hline
\end{tabular}

Majority of the respondents (83.59\%) had low level of knowledge regarding presence of lot of hidden disease, 8.59 and 7.82 per cent of the respondents were having medium and high level of knowledge, respectively regarding presence of lot of hidden disease.

Maximum number of the respondents $(87.50 \%)$ had low level of knowledge regarding knowledge about scientific methods of Parthenium weed control, whereas, 7.82 and 4.68 per cent of the respondents were having medium and high level of knowledge, respectively regarding knowledge about scientific methods of Parthenium weed control. It was found that majority of the respondents $(71.87 \%)$ had low level of knowledge regarding knowledge about mechanical method, whereas, 19.54 and 8.59 per cent of the respondents were having medium and high level of knowledge, respectively regarding knowledge about mechanical method.

Majority of the respondents (60.94\%) had low level of knowledge regarding knowledge about uprooting method, whereas, 28.91 and 10.15 per cent of the respondents were having medium and high level of knowledge, respectively regarding knowledge about uprooting method. It was found that majority of the respondents $(78.90 \%)$ had low level of knowledge regarding knowledge about precaution during uprooting method, whereas, 
14.85 and 6.25 per cent of the respondents were having medium and high level of knowledge, respectively regarding knowledge about precaution during uprooting method.

Majority of the respondents $(78.91 \%)$ had low level of knowledge regarding knowledge about cultural method, 17.97 and 3.12 per cent of the respondents were having medium and high level of knowledge, respectively regarding knowledge about cultural method.

It was found that majority of the respondents $(86.72 \%)$ had low level of knowledge regarding knowledge about advantages of cultural method, 9.37 and 3.91 per cent of the respondents were having medium and high level of knowledge, respectively regarding knowledge about advantages of cultural method.

Majority of the respondents (100\%) had low level of knowledge regarding knowledge about legal method, whereas, none of the respondents were having medium and high level of knowledge, respectively regarding knowledge about legal method.

Majority of the respondents (98.44\%) had low level of knowledge regarding knowledge about utilization method, followed by 1.56per cent respondents who were having medium knowledge regarding knowledge about utilization method, whereas none of the respondents were having high level of knowledge regarding knowledge about utilization method It was found that majority of the respondents (99.22\%) had low level of knowledge regarding knowledge about use of Parthenium weed on insecticidal and nematicidal form, followed by 0.78 per cent respondents who were having medium knowledge regarding knowledge about use of Parthenium weed on insecticidal and nematicidal form, whereas none of the respondents were having high level of knowledge regarding knowledge about use of Parthenium weed on insecticidal and nematicidal form.
It was found that majority of the respondents $(99.22 \%)$ had low level of knowledge regarding knowledge about for making acid and biogas form, followed by 0.78 per cent respondents who were having medium knowledge regarding knowledge about for making acid and biogas form, whereas none of the respondents were having high level of knowledge regarding knowledge about for making acid and biogas form.

It was found that majority of the respondents $(100 \%)$ had low level of knowledge regarding knowledge about for making card board, whereas, none of the respondents were having medium and high level of knowledge, respectively regarding knowledge about for making card board.

It was found that majority of the respondents $(100 \%)$ had low level of knowledge regarding knowledge about use of Parthenium weed on sericulture, whereas, none of the respondents were having medium and high level of knowledge, respectively regarding knowledge about use of Parthenium weed on sericulture.

It was found that majority of the respondents (100\%) had low level of knowledge regarding knowledge about for making compost, whereas, none of the respondents were having medium and high level of knowledge, respectively regarding knowledge about for making compost. It was found that majority of the respondents $(100 \%)$ had low level of knowledge regarding knowledge about use of Parthenium weed which stage on composting, whereas, none of the respondents were having medium and high level of knowledge, respectively regarding knowledge about use of Parthenium weed which stage on composting. It was found that majority of the respondents (100\%) had low level of knowledge regarding knowledge about nutrient status of Parthenium weed compost, whereas, none of the respondents were having medium and high level of knowledge, respectively regarding knowledge about nutrient status of Parthenium weed compost. 
It was found that majority of the respondents $(93.75 \%)$ had low level of knowledge regarding knowledge about chemical method, whereas, 3.13 of the respondents were having medium and high level of knowledge, respectively regarding knowledge about chemical method.

It was found that majority of the respondents (98.44\%) had low level of knowledge regarding knowledge about chemical quantity, followed by 1.56 per cent respondents who were having high knowledge regarding knowledge about chemical quantity, whereas none of the respondents were having medium level of knowledge about chemical quantity. It was found that maximum number of the respondents (96.09\%) had low level of knowledge regarding knowledge about when chemical method is applied according to day and time- interval, whereas, 2.35 and 1.56 per cent of the respondents were having high and medium level of knowledge, respectively regarding knowledge about when chemical method is applied according to day and time-interval.

It was observed that majority of the respondents (96.09\%) had low level of knowledge regarding knowledge about precaution during chemical method, whereas, 3.13 and 0.78 per cent of the respondents were having high and medium level of knowledge, respectively regarding knowledge about Precaution during chemical method. It was found that majority of the respondents (99.22\%) had low level of knowledge regarding knowledge about salt solution method, followed by 0.78 per cent respondents who were having high knowledge regarding knowledge about salt solution method, whereas none of the respondents were having medium level of knowledge about salt solution method. It was observed that majority of the respondents (99.22\%) had low level of knowledge regarding knowledge about biological method, followed by 0.78 per cent respondents who were having high knowledge regarding knowledge about biological method, whereas none of the respondents were having medium level of knowledge about biological method.
It was found that majority of the respondents $(99.22 \%)$ had low level of knowledge regarding knowledge about fungal method, followed by 0.78per cent respondents who were having high knowledge regarding knowledge about fungal method, whereas none of the respondents were having medium level of knowledge about fungal method.

It was found that majority of the respondents $(100 \%)$ had low level of knowledge regarding knowledge about bacterial method, whereas, none of the respondents were having medium and high level of knowledge, respectively regarding knowledge about bacterial method. It was found that majority of the respondents (99.22\%) had low level of knowledge regarding knowledge about insect method, followed by 0.78 per cent respondents who were having high knowledge regarding knowledge about insect method, whereas none of the respondents were having medium level of knowledge about insect method.

It was observed that majority of the respondents (99.22\%) had medium low level of knowledge regarding knowledge about cultural method, followed by 0.78 per cent respondents who were having medium knowledge regarding knowledge about cultural method, whereas none of the respondents were having high level of knowledge regarding knowledge about cultural method.

It was found that majority of the respondents $(100 \%)$ had low level of knowledge regarding knowledge about flowers method, whereas, none of the respondents were having medium and high level of knowledge, respectively regarding knowledge about flowers method.

It was found that maximum number of the respondents $(100 \%)$ had low level of knowledge regarding knowledge about other methods, whereas, none of the respondents were having medium and high level of knowledge, respectively regarding knowledge about other methods. 
It was observed that majority of the respondents (39.84\%) had medium level of knowledge regarding knowledge about surrounding area covered under Parthenium weed, whereas, 32.82 and 27.34 per cent of the respondents were having low and high level of knowledge, respectively regarding knowledge about surrounding area covered under Parthenium weed. It was found that majority of the respondents $(55.46 \%)$ had low level of knowledge regarding knowledge about field area which is effected by Parthenium weed, whereas, 27.35 and 17.19 per cent of the respondents were having medium and high level of knowledge, respectively regarding knowledge about field area which is effected by Parthenium weed.

It was observed that majority of the respondents $(68.76 \%)$ had low level of knowledge regarding knowledge about yield loss due to Parthenium weed, 15.62 per cent of the respondents were having medium and high level of knowledge, respectively regarding knowledge about yield loss due to Parthenium weed. It can be concluded that per cent of the respondents had medium level of knowledge regarding knowledge about Parthenium weed, 87.5 per cent, 71.87 per cent, 60.93 per cent, 78.90 per cent, 100 per cent, 98.43 per cent, 93.75 per cent, 99.21 per cent of the respondents had low level of knowledge regarding control measure practices of Parthenium weed, respectively, whereas the respondents 8.59 per cent scientific,19.53 per cent mechanical, 28.90per cent uprooting, 17.96 per cent cultural, and utilization, 1.56per cent in other and 3.12 per cent chemical methods of the respondents had medium level of knowledge regarding of the control measure practices of Parthenium weed, and 4.68per cent scientific, 8.59 per cent mechanical, 10.15 per cent uprooting, 3.12 per cent cultural, and chemical methods and 0.78per cent biological methods of the respondents had low level of knowledge regarding of the control measure practices of Parthenium weed.

After complementation of study, it is conclude that mostly respondents had low level of knowledge regarding control measure of parthenium weed followed by medium level of knowledge and only few respondents have high knowledge about control measure of parthenium weed.

\section{References}

Jayakumar, R., M. Mahadevappa, S. Joshi and T.G. Prasad (1989). Dormancy studies in Cassia sericea seeds. Seed Res., 17(2): 118-121.

Krishnamurthy, K., T. V. R. Prasad and T. V. Muniyappa (1976). Ecology and control of Parthenium. In: Parthenium - Positive danger, Proc. of the seminar held on Sept. 4, 1976, UAS Tech. Series, No. 16: 1-5.

Lonkar, A., J. C. Mitchell and C. D. Calnan (1974). Contact dermatitis from Parthenium hysterophorus. Trans. St. John's Hospital Dermatological Soc., 60: 43-43.

Rao, R. S. (1956). Parthenium, a new record for India. J. Bombay Nat. Hist. Soc., 54: 218220.

Vertak, V. D. (1968). Weed that threatens crop and grasslands in Maharashtra. Indian Fmg, 18: 23-24.

\section{How to cite this article:}

Singh, D.V., Anupam Mishra, S.R.K. Singh and Tushar Athare. 2017. Knowledge Level of Tribal Farmers Regarding Parthenium (Parthenium hysterophorus L.) Weed and their Control Actions. Int.J.Curr.Microbiol.App.Sci. 6(12): 3869-3877. doi: https://doi.org/10.20546/ijcmas.2017.612.447 